\title{
Scenario of Sthree Shakthi Self Help Groups and Members in Dharwad and Tumkur Districts of Karnataka, India
}

\author{
J.M. Saraswathi ${ }^{1}{ }^{*}$, Nagaraj $^{2}$ and P.R. Sumangala ${ }^{1}$ \\ ${ }^{1}$ Department of Family Resource Management, Rural Home Science College, University of \\ Agricultural Sciences, Dharwad-580005, Karnataka, India \\ ${ }^{2}$ Department of Agricultural Extension, University of Agricultural Sciences, GKVK, \\ Bengaluru- 560 065, Karnataka, India
}

*Corresponding author

\section{A B S T R A C T}

\section{Keywords}

Sthree Shakthi self

help groups.

Performance

indicators, Self help

group members,

Sthree Shakthi

Programme,

SHG/SHGs (Self

Help Group/s)

Article Info

\section{Accepted:}

07 November 2018

Available Online:

10 December 2018
The present study was conducted during 2013-14 n Karnataka state both n Northern (Dharwad) and Southern (Tumkur) districts of Karnataka. This study was conducted mainly to assess the scenario of Sthree Shakthi Self Help Groups as well as members in the study areas. It was observed from the study that more than eighty percent of the Dharwad and seventy percent of Tumkur women members have joined Sthree Shakthi Self Help Groups to sport family income and to attain financial security respectively. Among Dharwad respondents, agriculture (77\%) was found to be the main reason for availing the loan from Sthree Shakthi Self Help Groups followed by animal husbandry (48.16\%). Similarly in Tumkur district, agriculture (78.33\%) was the main reason followed by income generation activities $(54.44 \%)$ for loan availment. Thus, SSGs from both the selected districts were found to be on par with respect to performance even with varied sample size but, Z-values of the table indicated that they differ significantly for microenterprise development and for total at five percent level. The greater percentage of groups were categorized as good in case of Dharwad (66.70\%) and very good in Tumkur $(66.67 \%)$ districts.

\section{Introduction}

The concept of SHG stands to underline the principle 'for the people', 'by the people' and 'of the people'. SHG phenomenon is an important means of development offering an approach which puts people for collective action and co-ordinated management system (Fernandez, 2006). The SHG concept was originated during early 1980s and experimental attempt was made in the neighboring country i.e. Bangladesh by Dr. Mohammed Yunus, former Head of the Department of Economics, Chittagong University.

The status of women in any society is an indicator of the level of its development 
because in the society women play critical roles in the family and outside. National Bank for Agriculture and Rural Development (NABARD) defines Sthree Shakthi programme is an approach through which efforts are being made by the government with the intention to pool both human and material resources to empower women in rural areas. Sthree Shakthi programme has been implemented throughout the state during 2000-2001 by the Honorable Chief minister Sri S. M. Krishna. Sthree Shakthi Self Help Groups have formed through the Anganawadi workers in the rural areas of each taluk. About 15 to 20 lakhs women have organized under this scheme consisting of 15 to 20 women in each group and in recent years, empowerment of women has been recognized as a central issue (Bhagyalakshmi, 2004). Implementation and monitoring of the scheme is given to the Department of Women and Child Development (W\&CD). Child Development Project Officer (CDPO) is monitoring the programme by the assistance of field staffs (Anganawadi Supervisors and Anganawadi Workers). Homogeneity (members belonging to the same income or social strata) contributes much to the group success. Because, members with similar social background exhibit similar coping behavior in times of stress and will thus able to extend mutual support (Suguna, 2006). Full participation of group members and transparently in group operations (financial) and functioning (which promotes trust, mutual faith and confidence) are important contributing factors for success of SHGs (Singh and Josh, 1995). Thus, sustainable development of women's resources like their abilities, interests, skills and their potentialities are of paramount importance for the development human resources (Mehta and Sethi, 1997). In nut shell, women have a profound and pervasive effect on the health and happiness of their families, communities and local ecosystem (Gupta, 2000).
Performance refers to the adoptability, pattern of functioning and their contribution. The assessment of performance level of SSGs will be valuable information for the implementing agencies as well as policy makers to enhance performance if they were lagging in any particular area. With this intention, performance level of SSGs of the selected districts i.e. Dharwad (12 SSGs) and Tumkur (18 SSGs) was measured. Hence the present study was carried out with the following objective:

1. To study the Scenario of Sthree Shakthi Self Help Groups and Members in Dharwad and Tumkur Districts of Karnataka

\section{Materials and Methods}

The present investigation was an exploratory research design and this study was conducted purposively in Tumkur and Dharwad districts of Karnataka during 2013-14. Two districts namely, Dharwad and Tumkur were selected based on purposive sampling technique. From the selected districts, based on proportionate sampling two taluks from Dharwad districs namely Dharwad and Kalghatagi taluks were selected. Similarly, four taluks namely Pavagada, Kortagere, Chikkanayakanahalli and Tiptur taluks were selected from Tumkur district. Three villages from Dharwad and five villages from Kalghatagi taluks were selected. From Pavagada and Tiptur taluks two and four villages were selected respectively. In case of Kortagere and Chikkanayakanahalli taluks, one village from each taluk was selected. Totally, 16 villages were selected purposively and thirty Sthree Shakthi Groups were selected from those sample villages. Out of thirty Sthree Shakthi Groups 300 Sthree Shakthi Self Help Group members were selected as a sample respondents. Prestructured questionnaire was the research tool used to collect the required information from the sample under the study. 


\section{Results and Discussion}

The data presented under the table 1 revealed the reasons for joining SSGs of Dharwad and Tumkur districts. It was clear from the table that, the majority of women members of Dharwad joined SSGs to support family income $(81.66 \%)$, to improve their savings practice $(79.16 \%)$ and to get the loan from banks $(75.85 \%)$. It was very interesting to know the fact that nearly 70 percent of the women members joined SSGs to attain financial security $(68.33 \%)$ and also to provide better education for their children $(67.50 \%)$. For equal percentage $(57.50 \%)$ of women members, attaining economic independence and to get recognition from the society were the reasons to take membership in SSGs. However, good percentage of women members have joined SSGs to take up income generating activities (45.83\%) but meager percentage of women joined SSGs to exhibit their talents and to avoid getting bored at home $(5.83 \%)$.

Table 2 discloses the reasons for which the SSG members have availed loan from their groups. Among Dharwad respondents, agriculture $(77 \%)$ was found to be the main reason followed by animal husbandry
(48.16\%) and for about 45 percent of the SSG members income generation activities $(44.99 \%)$ and education $(44.16 \%)$ were the reasons to avail loan from the SSGs. Apart from this, a good percentage of respondents availed loan for social events (42\%) and health $(41.66 \%)$ reasons when compared to household expenses (15\%) and irrigation $(02.49 \%)$ was found to be the least reason. In the study conducted by Rajendra and Raya (2011) it was found similar to the present study results. The authors revealed that the animal husbandry was the major reason to avail loan from the SHGs for greater percentage $(31.30 \%)$ of members.

Similarly, for Tumkur respondents agriculture $(78.33 \%)$ was the main reason followed by income generation activities (54.44\%) and animal husbandry to avail loan from SSGs. Anyhow, a good percentage of members availed loan for irrigation (31.66\%) and educational $(31.11 \%)$ reasons when compared to house hold expenses $(25.55 \%)$. As per the table, very few percentage of SSG members from both the districts availed loan for reasons such as loan repayment, asset purchase and construction works (house and toilet).

Table.1 Reasons for joining Sthree Shakthi Groups in Dharwad and Tumkur districts

\begin{tabular}{|c|c|c|c|}
\hline & & & $N=30$ \\
\hline *Reasons & $\begin{array}{c}\text { Dharwad } \\
(\mathrm{n}=120)\end{array}$ & $\begin{array}{l}\text { Tumkur } \\
(\mathrm{n}=180)\end{array}$ & Total \\
\hline To attain economic independence & $69(57.50)$ & $31(17.22)$ & $100(33.33)$ \\
\hline Bored at home & $07(05.83)$ & 14(07.77) & $21(07.00)$ \\
\hline To get recognition from the society & $69(57.50)$ & $92(51.11)$ & 161(53.66) \\
\hline To improve savings practice & $95(79.16)$ & $156(86.66)$ & 251(83.66) \\
\hline To show talents & $17(14.16)$ & $06(03.33)$ & $23(07.66)$ \\
\hline To get the loan from banks & $91(75.83)$ & $123(68.33)$ & 214(71.33) \\
\hline To support family income & $98(81.66)$ & $165(91.66)$ & 263(87.66) \\
\hline To give better education to the children & $81(67.50)$ & 143(79.44) & 224(74.66) \\
\hline To attain financial security & $82(68.33)$ & $145(80.55)$ & $227(75.66)$ \\
\hline To start income generation activities & $55(45.83)$ & 77(42.77) & $132(44.00)$ \\
\hline
\end{tabular}

*Multiple responses

*Figures in the parenthesis indicate percentage 
Table.2 Reasons for availing internal loan by Sthree Shakthi members in selected districts of Karnataka

\begin{tabular}{|c|c|c|c|}
\hline & & & $\mathbf{N}=\mathbf{3 0 0}$ \\
\hline *Reasons & $\begin{array}{c}\text { Dharwad } \\
(n=120)\end{array}$ & $\begin{array}{l}\text { Tumkur } \\
(n=180)\end{array}$ & Total \\
\hline Agriculture & $93(77.16)$ & $141(78.33)$ & $234(78.00)$ \\
\hline Irrigation & $03(02.49)$ & $57(31.66)$ & $60(20.00)$ \\
\hline Animal husbandry & $58(48.16)$ & $75(41.66)$ & $133(44.33)$ \\
\hline House hold expenses & $18(15.00)$ & $46(25.55)$ & $64(21.33)$ \\
\hline Social events & $50(42.00)$ & $9(05.00)$ & $59(19.66)$ \\
\hline Health & $50(41.66)$ & $37(20.55)$ & $87(29.00)$ \\
\hline Education & $53(44.16)$ & $56(31.11)$ & $109(36.33)$ \\
\hline Loan repayment & $09(07.50)$ & $18(10.00)$ & 27(09.00) \\
\hline Income generation activities & $54(44.99)$ & $98(54.44)$ & $152(50.66)$ \\
\hline Asset purchase & $06(05.10)$ & $9(05.00)$ & $15(05.00)$ \\
\hline House construction & $06(05.10)$ & $11(06.11)$ & $17(05.66)$ \\
\hline Toilet construction & $05(04.16)$ & $6(03.33)$ & $11(03.66)$ \\
\hline
\end{tabular}

Table.3 Z- values for performance indicators among Dharwad and Tumkur districts Sthree Shakthi Groups

\begin{tabular}{l} 
Performance indicators \\
\hline Organizational capacity \\
\hline Savings \& credit \\
\hline Financial management \\
\hline Microenterprise development \\
\hline Networks \& linkages \\
\hline Influence on Group affairs \\
\hline Total
\end{tabular}

*Significant at 5 percent level

\begin{tabular}{|c|c|c|c|c|}
\hline \multirow{2}{*}{\multicolumn{2}{|c|}{ Dharwad (n=12) }} & & \multicolumn{2}{|c|}{$\mathrm{N}=30 \mathrm{SSGs}$} \\
\hline & & \multicolumn{2}{|c|}{ Tumkur (n=18) } & \multirow[t]{2}{*}{ Z-value } \\
\hline Mean & Std & Mean & Std & \\
\hline 31.17 & 1.47 & 32.17 & 2.01 & $1.35 \mathrm{NS}$ \\
\hline 24.42 & 1.00 & 24.94 & 0.94 & $1.44 \mathrm{NS}$ \\
\hline 11.00 & 0.00 & 10.94 & 0.24 & $0.86 \mathrm{NS}$ \\
\hline 4.33 & 0.78 & 5.33 & 0.97 & $2.98 *$ \\
\hline 4.67 & 0.78 & 4.83 & 0.71 & $0.58 \mathrm{NS}$ \\
\hline 9.00 & 0.00 & 9.00 & 0.00 & 0 \\
\hline 84.58 & 2.87 & 87.22 & 2.90 & $2.45 *$ \\
\hline
\end{tabular}

NS: non significant

Table.4 Level of performance of Sthree Shakthi Groups in sample areas based on selected indicators

\begin{tabular}{|l|c|c|c|}
\hline \multicolumn{1}{|c|}{ Level of performance } & \multicolumn{3}{|c|}{ N=30 SSGs } \\
\hline Good $(<\mathbf{8 5})$ & 08 & 02 & Total \\
\hline Very good (85 to 88) & $(66.70)$ & $(11.11)$ & 10 \\
& 03 & 12 & $133.33)$ \\
\hline Excellent $(>\mathbf{8 8})$ & $(25.00)$ & $(66.67)$ & $(50.00)$ \\
\hline
\end{tabular}

Figures in the parenthesis indicates percentage 
However, overall impression unfolds the fact that irrespective of districts agriculture served as major reason for majority of members to avail loan from SSGs.

As per the table 3, the mean differences between Dharwad and Tumkur for almost all the indicators were very narrow even with varied sample size. Thus, SSGs from both the selected districts were found to be on par with respect to performance but, $\mathrm{Z}$-values of the table indicated that they differ significantly for microenterprise development and for total at five percent level.

The findings of the study conducted by Das (2012) were in contradiction to the present study findings. The reported findings of Das indicated that more than 54 per cent of the selected SHGs in the selected districts of Assam were earmarked as 'poor' (mean score $=20-30$ ) based on their performance and only eight per cent of them were from good (mean score $=50$ ) category.

Further, the level of performance of SSGs was classified as good $(<85)$, very good (85 to 88 ) and excellent (>88) based on mean and Standard deviation (Table 4). It was also showed that, the greater percentage of groups were categorized as good in case of Dharwad $(66.70 \%)$ and Very good in Tumkur $(66.67 \%)$ districts.

Anyhow, the percentage distribution for excellent groups in both the districts was found to be less i.e. 8.30 percent for Dharwad and 22.22 percent for Tumkur when compared to good and very good SSGs.

\section{References}

Bhagyalakshmi, J., 2004, Women empowerment - Miles to go, Yojana a development monthly, 14(3): 24-28.

Fernandez, A.P., 2006, History and spread of Self Help Affinity Group movement in India. Discussion Paper 3, Asia and Pacific Division, Rome: IFAD.

Gupta, 2000, Strategy for empowerment of women through Self Help Groups in YSR district. Indian J. Mktg., 33(6): 1216.

Mehta and Sethi, 1997, Success story of integrated fish farming - A self help group approach. Agric. Ext. Rev., 52(13): 33-38.

Singh and Josh, 1995, Micro credit through Self-Help Groups. J. Agric. Extn., 110(1): 24-30.

Suguna, 2006, An alternative strategy for poverty alleviation. Kisan World, 32(3): 49-50.

Das, S.K., 2012, Best practices of Self Help Groups and women empowerment: A case of Barak valley of Assam. Far East J. Psychol. Busi., 7(2): 29-50.

Rajendra, K. and Raya, R.P., 2011, Role of non-governmental organizations in micro finance through SHGs - A study in Vellore district of Tamil Nadu. $J$. Arts, Sci. Comm., 2(4): 203-213.

\section{How to cite this article:}

Saraswathi, J.M., Nagaraj and Sumangala, P.R. 2018. Scenario of Sthree Shakthi Self Help Groups and Members in Dharwad and Tumkur Districts of Karnataka, India. Int.J.Curr.Microbiol.App.Sci. 7(12): 782-786. doi: https://doi.org/10.20546/ijcmas.2018.712.097 